\title{
Evaluation of Cerebral Arteriovenous Malformations Using Image Fusion Combining Three-Dimensional Digital Subtraction Angiography with Magnetic Resonance Imaging
}

\author{
Üç Boyutlu Dijital Subtraksiyon Anjiyografisinin Manyetik Rezonans \\ Görüntüleme ile Kombine Edilmesiyle Görüntü Füzyonu Kullanılarak \\ Serebral Arteriyovenöz Malformasyonlarn Değerlendirilmesi
}

\author{
Hidenori SUZUKI ${ }^{1}$, Hiroaki MAKI ${ }^{2}$, Waro TAKI ${ }^{1}$ \\ ${ }_{1}^{1}$ Mie University, Graduate School of Medicine, Department of Neurosurgery, Tsu/Mie, Japan \\ ${ }^{2}$ Mie University, Graduate School of Medicine, Department of Radiology, Tsu/Mie, Japan
}

Correspondence address: Hidenori SUZUKI / E-mail: mie1192suzuki@gmail.com

\begin{abstract}
AIM: An image fusion of 3-dimensional (D) digital subtraction angiography (DSA) and magnetic resonance (MR) images, DSA-MR fusion, can simultaneously visualize both information of the vasculature provided by 3D DSA and of the soft tissues provided by MR images. The authors assessed the usefulness of DSA-MR fusion images concerning the pretreatment evaluation for cerebral arteriovenous malformation (AVM).

MATERIAL and METHODS: Seven consecutive patients underwent pretreatment DSA-MR fusion and then microsurgical, endovascular and/ or radiosurgical treatments.

RESULTS: DSA-MR fusion images clearly showed the spatial relationship among AVM, its feeding artery, draining vein, surrounding artery feeding the normal brain tissue, hematoma and brain tissues (gyri or brain surface) with reasonable post-processing time.

CONCLUSION: These findings were useful for treatment planning for AVM, especially to enable neurosurgeons to easily understand the surgical anatomy preoperatively.
\end{abstract}

KEYWORDS: Angioarchitecture, Intracerebral hemorrhage, Surgical anatomy, Treatment planning

öz

AMAÇ: 3 boyutlu dijital subtraksiyon anjiyografisi (DSA) ve manyetik rezonans (MR) görüntülerinin bir görüntü füzyonu olan DSA-MR füzyonu hem 3D DSA tarafından sağlanan damar sistemi bilgisini hem de MR görüntüleri tarafından sağlanan yumuşak doku görüntülerini aynı anda gösterebilir. Yazarlar serebral arteriyovenöz malformasyonu (AVM) tedavi öncesi değerlendirilmesiyle ilgili olarak DSA-MR füzyon görüntülerinin faydasını incelemiştir.

YÖNTEM ve GEREÇLER: Arka arkaya yedi hastada tedavi öncesi DSA-MR füzyonu ve sonrasında mikrocerrahi, endovasküler ve/veya radyocerrahi tedavileri yapılmıştır.

BULGULAR: DSA-MR füzyonu görüntüleri AVM, besleyen arter, drenaj veni, normal beyin dokusunu besleyen çevre arterler, hematom ve beyin dokuları (giruslar veya beyin yüzeyi) arasındaki uzaysal ilişkiyi makul bir inceleme sonrası süre kullanılmasıyla açık olarak göstermiştir.

SONUÇ: Bu bulgular AVM tedavisi planlaması ve özellikle beyin cerrahlarının cerrahi anatomiyi preoperatif olarak kolayca anlamalarını sağlamak üzere faydalı bulunmuştur.

ANAHTAR SÖZCÜKLER: Anjiyomimari, İntraserebral kanama, Cerrahi anatomi, Tedavi planlama

\section{INTRODUCTION}

The management of arteriovenous malformation (AVM) consists of determining the treatment modality, or combination of modalities, with the greatest therapeutic effectiveness and safety according to both patient characteristics and AVM architecture (6). AVM architecture is critical in formulating the most effective treatment plan.
Magnetic resonance (MR) imaging and digital subtraction angiography (DSA) are used to obtain detailed preoperative angiographic clarification of the AVM anatomy, architecture, and associated aneurysms. Recently, an image fusion of 3-dimensional (D) DSA and MR images, DSA-MR fusion, has entered clinical use $(5,7,8)$. This image fusion is expected to make up for the shortcomings of 3D DSA and MR images 
and to add up their advantages: that is, it can simultaneously visualize both information of the vasculature provided by 3D DSA and of the soft tissues provided by MR images (5). However, it is unknown whether DSA-MR fusion provides more useful information regarding the treatment planning for AVM than analyzing 3D DSA and MR images separately. The goal of this study was to assess whether DSA-MR fusion is worthwhile over analyzing 3D DSA and MR images separately in pretreatment evaluations for AVM.

\section{MATERIAL and METHODS}

\section{Patient population}

Image fusion was performed in 7 consecutive patients with AVM presenting with intracerebral hemorrhage (Table I). Appropriate informed consent was obtained from the patients or their relatives. No procedure-related morbidity or mortality occurred, and the examination was well tolerated by all 7 patients.

\section{DSA-MR fusion}

Standard 2D DSA was initially performed, and thereafter 3D DSA (LCN+; GE Medical Systems) was performed as described previously $(5,7,8)$. The 3D spoiled gradient recalled (SPGR) MR images were obtained with a $1.5 \mathrm{~T}$ superconducting unit (Signa; GE Medical Systems) using a standard quadrature head coil after intravenous injection of gadopentetate dimeglumine (Magnevist; Berlex, Montville, NJ) at a dose of $0.1 \mathrm{mmol} / \mathrm{kg}$ as described previously $(5,7,8)$. If necessary, the 3D SPGR images were twice obtained and resulted in an overall vessel coverage of $152 \mathrm{~mm}$. The 3D DSA (maximum intensity projection; MIP) and SPGR MR images were fused on the workstation using prototype image fusion software called XR/MR Fusion (GE Medical Systems) as described previously $(5,7,8)$. The registration procedure started with the manual designation of a pre-defined anatomical point in both modalities, and then automatically registered. The whole registration process took less than 30 seconds per case. When it was completed, we validated (and manually fine-tuned if required) the registration identified by the software.

This software provided several methods to display the fused 3D DSA and MR images. The methods used in this study were called "Common Cursor", "Thick Slice", and "Sector". With the
"Common Cursor" method, 4 images from one 3D DSA (MIP), three cross-sectional MR images (axial, coronal and sagittal) and one fused 3D DSA and MR image were displayed at the same time on the monitor. When clicking on any point on any of the 4 images, the software indicated automatically and in real-time the corresponding points on the other three images. The "Thick Slice" method showed a volume rendering image in which two thick slices (axial, coronal or sagittal 3D DSA and MR slices) were superimposed: the 3D DSA slice was thicker than the MR slice. The "Sector" method showed the volume rendering image in which the whole 3D DSA vasculature was superimposed on two or three cross-sectional MR slices (axial, coronal or sagittal), whose thickness could be changed.

\section{Evaluations}

Two experienced neurosurgeons (HS, WT), who were experienced in performing microsurgical, endovascular and radiosurgical treatments, independently reviewed 3D DSA, 3D contrast-enhanced SPGR MR and DSA-MR fusion images. For analysis, each image was presented on the monitor screen of the workstation. Three-dimensional DSA images were evaluated from the desired angles using MIP and volumerendering images. Three cross-sectional MR images (axial, coronal and sagittal) were evaluated using sequential multiple slices. DSA-MR fusion images were evaluated using different display modes: the authors at first assessed the Common Cursor images, and then assessed the other DSA-MR fusion images. Two experienced neurosurgeons independently judged whether the additional information provided by the DSA-MR fusion images was useful for treatment planning or not. Differences in assessment were resolved by consensus.

\section{RESULTS}

The additional information which was obtained by DSA-MR fusion but were not or difficultly obtained by analyzing 3DDSA or MR images separately was as follows: (a) the passing course of a feeding artery, a draining vein of AVM or the surrounding arteries in the brain tissue and (b) the spatial relationship among AVM, its feeding artery, draining vein, surrounding artery feeding the normal brain tissue, hematoma and brain tissues. The former information was considered useful for predicting the functional risks associated with unexpected vessel injuries during direct surgery or endovascular treatment,

Table I: Patient Population

\begin{tabular}{|c|c|l|l|c|l|}
\hline No. & Age & Sex & Location & SM grade & Treatment \\
\hline 1 & 27 & Female & Left occipital lobe & III & Gamma knife \\
\hline 2 & 55 & Male & Right frontal lobe & III & TAE + Gamma knife \\
\hline 3 & 29 & Female & Left occipital lobe & III & TAE + Gamma knife \\
\hline 5 & 26 & Male & Right temporal lobe & II & Surgery \\
\hline 6 & 33 & Male & Left temporal lobe & III & Surgery \\
\hline 7 & 66 & Male & Right frontal lobe & II & Gamma knife \\
\hline
\end{tabular}

SM grade, Spetzler and Martin grade; TAE, transarterial embolization. 
and therefore for the patient's pretreatment education, although no unexpected vessel injuries occurred during AVM treatment in this study. The latter information was useful for clarifying the boundary of AVM and therefore for radiosurgical planning, because AVM was associated with intracerebral hemorrhage that compromised MR images in this study. In addition, DSA-MR fusion images enabled neurosurgeons to understand the surgical anatomy preoperatively and were useful for surgical planning for AVM: neurosurgeons could easily interrupt the feeding arteries before the draining veins were interrupted. In contrast with 3D DSA that provided no

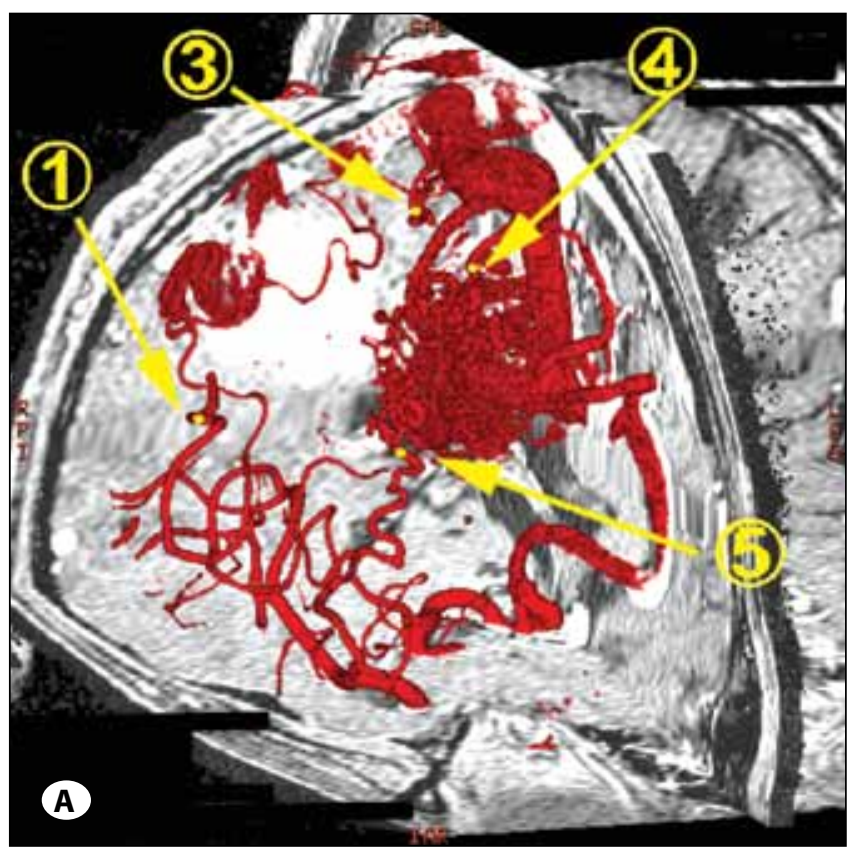

information other than vessels, 3D contrast-enhanced SPGR $M R$ images showed cerebral arteries including perforating arteries as high intensity spots or strings in the brain tissue, as well as draining veins. However, MR images alone could not exactly demonstrate the passing course of an artery in the brain tissue, even though the artery was traced carefully on adjacent images. MR images also showed the relationships among the nidus, vessels, hematoma and brain tissue, and made an overall evaluation of axial images by changing the section direction. However, MR images could not consistently visualize the nidus, the courses of the feeding, passing arteries and draining veins, brain tissue and hematoma on the same plane, and therefore the $3 \mathrm{D}$ relationship among them had to be deduced. As a result, 2 neurosurgeons consistently judged that DSA-MR fusion images were more useful for treatment planning than separately used 3D DSA and MR images in all 7 cases.

\section{Illustrative cases}

1. Right frontal AVM (patient No. 2; Figure 1A,B)

DSA-MR fusion images clearly showed the passing course of feeding arteries of AVM in the brain tissue and a spatial relationship among $\mathrm{AVM}$, hematoma and brain tissue within 30 minutes. Common Cursor images easily identified the passing course of the specific feeding arteries in the brain tissue by showing the corresponding points among 3D DSA (MIP), MR and Sector images, and tracing the artery on the MIP image.

\section{Left temporo-parietal AVM (patient No. 7; Figure 2)}

The DSA-MR fusion images clearly delineated the AVM nidus and showed the spatial relationship among the nidus, a major

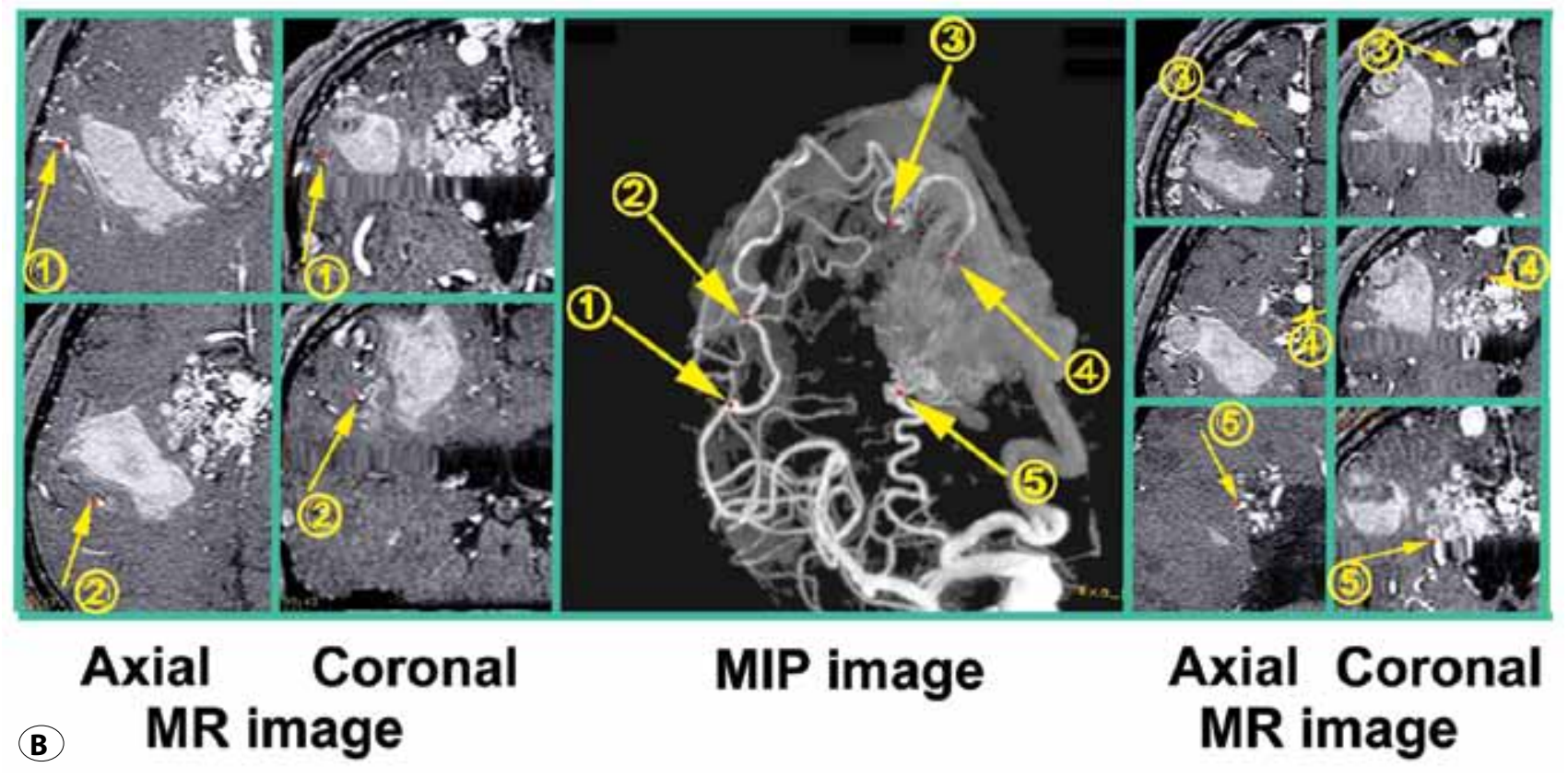

Figure 1: DSA-MR fusion images of right frontal AVM (patient No. 2). A) Sector image; B) Common Cursor image. The corresponding points are indicated as small dots and appear by number. 

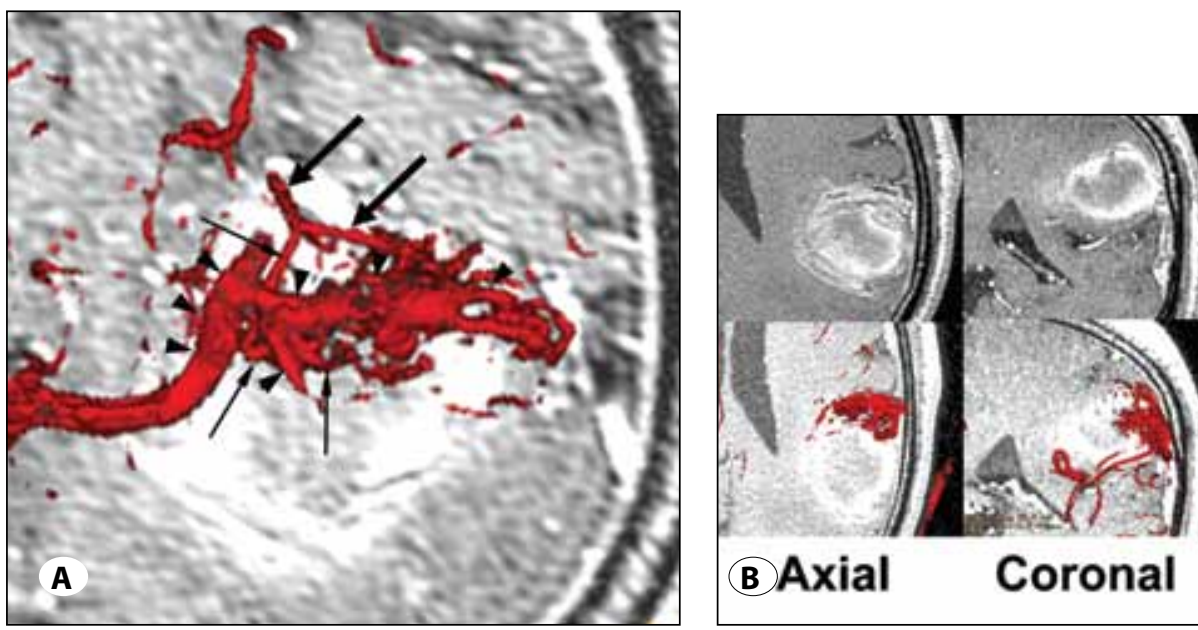

\section{BAxial Coronal}

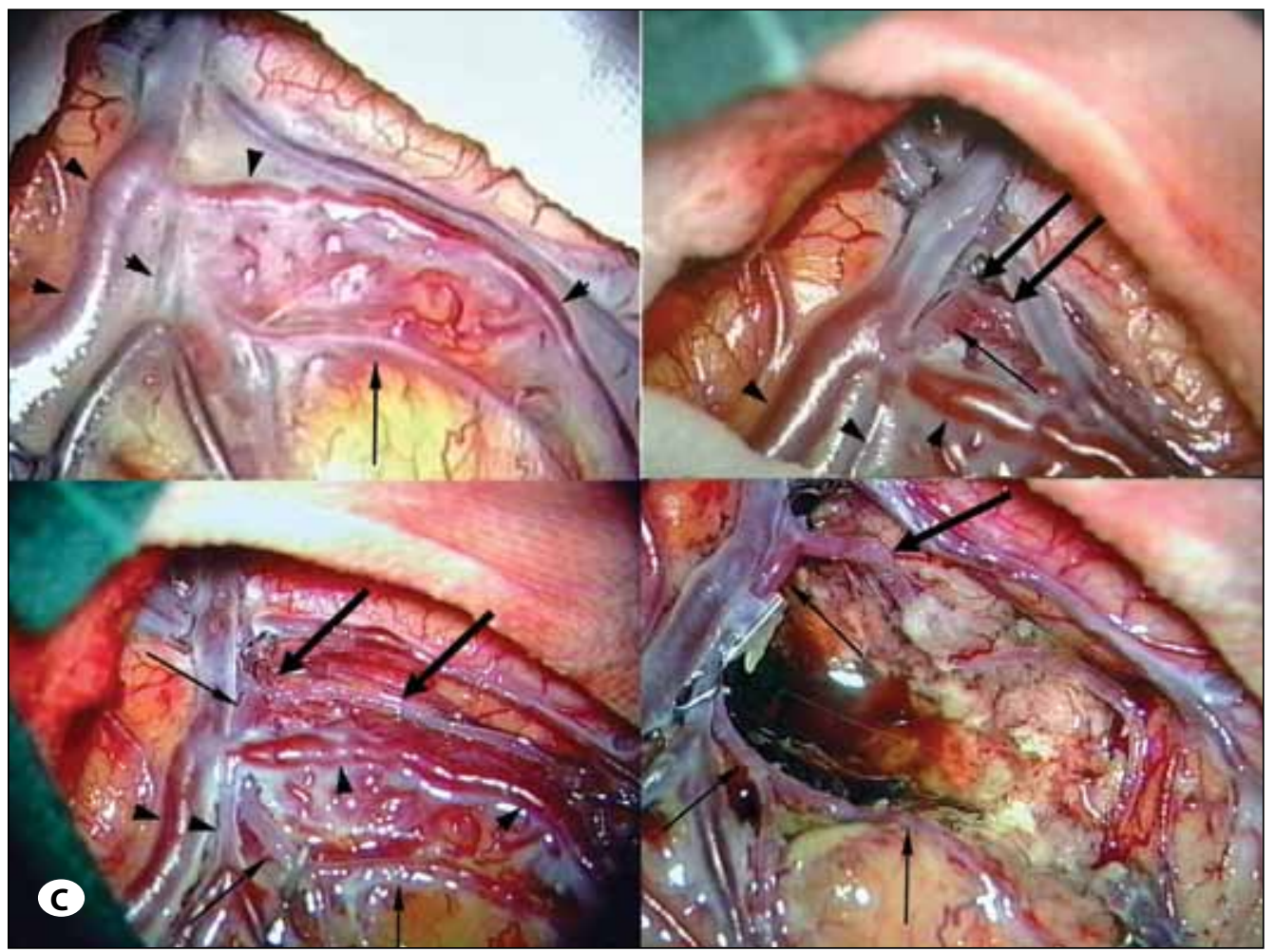

Figure 2: Left temporoparietal AVM (patient No. 7). A) Thick Slice image (surgical perspective display);

B) MR (upper) and Thick Slice (lower) images; C) operative views (left upper, brain surface; right upper or left lower, after dissecting arachnoid membrane around the feeding artery or AVM nidus, respectively; right lower, after removal of AVM). Thick arrows, feeding arteries; thin arrows, passing arteries; arrowheads, draining veins. feeding artery, a passing artery, draining veins, hematoma and brain tissue within 30 minutes (Figure 2A,B). MR imaging display of the AVM was compromised by the overlying signal of the hematoma, which did not cause poor visualization of AVM on the DSA-MR fusion images (Figure 2B). Surgical perspective display of the DSA-MR fusion image (Figure 2A) corresponded to the actual operative views (Figure $2 \mathrm{C}$ ). The information of DSA-MR fusion images enabled us easily to interrupt the major feeding artery on the brain surface. After that, we evacuated the AVM nidus. The location of the AVM nidus was delineated from the brain surface using draining veins as a landmark on the DSA-MR fusion images. Operative findings confirmed the findings of the DSA-MR fusion images.

\section{DISCUSSION}

Less invasive 3D computed tomography angiography and contrast enhanced MR imaging or angiography are helpful for the detection and characterization of cerebral AVMs, and also give information about the vasculature and the soft tissues. However, conventional angiography or DSA remains the gold standard for the study of cerebral AVM, because these less invasive techniques (although they are rapidly advancing) have inferior spatial resolution, do not enable imaging of the entire cerebral vasculature and do not provide precise information about intracranial hemodynamics. This study demonstrated that DSA-MR fusion images provided useful information for planning surgical or radiosurgical strategies by showing the surgical anatomy or clarifying the boundary 
of AVM associated with hematoma, and for predicting the functional risks associated with unexpected vessel injuries during direct surgery or endovascular treatment. The information could be to some extent drawn from appropriate and careful reading of DSA and MR images, but DSA-MR fusion images more easily and clearly provided them. In addition, DSA-MR fusion images caused neither additional invasiveness nor burden in AVM patients who underwent both 3D DSA and MR imaging.

Three-dimensional MR angiography allows an overall view of the AVM angioarchitecture with accentuation of vessels with high blood flow velocities. The well-known limitations of MR angiography include difficulties in correctly demonstrating vessels with flow turbulence or low-flow conditions including the venous drainage patterns (4). MR angiography may also fail both, in the exact delineation of feeding arteries due to vessel overlap and suppression of in-plane flow, as well as in the detection of the nidus in small AVMs due to limited spatial resolution. In addition, disturbances caused by structures with short T1 times, e.g., methemoglobin in subacute hemorrhage, may mask vascular components of the AVM (1). Although contrast-enhanced gradient-echo MR imaging and MR angiography have the potential advantage that smaller, slow-flow or turbulent-flow arteries and veins can be demonstrated, involved or surrounding vessels may not be clearly differentiated from an enhanced structure or subacute hemorrhage $(7,9)$.

The usefulness of the fusion images of computed tomography angiography, MR imaging, MR angiography or venography in AVM surgery recently has been reported, but the limited spatial resolution was still problematic (3). As shown in this report, DSA-MR fusion image is an imaging technique that may most clearly visualize both the AVM angioarchitecture and the surrounding tissues. DSA-MR fusion image is invasive but the patient who undergoes 3D DSA and MR imaging has no additional invasiveness, because DSA-MR fusion images are created on the workstation using image fusion software. The current limitation of DSA-MR fusion images is the lack of information about the velocity of blood flow within the different parts of the AVM. However, this information can be obtained by 2D DSA performed preceding 3D DSA.

DSA-MR fusion images are very useful for surgical planning. AVM surgery involves first identification of the malformation and then elimination of superficial feeding vessels, circumferential dissection leading to lesion apex, and finally division of the last vasculature pedicle with complete removal. Features important for the preoperative evaluation include depiction of the vessels, differentiation between arteries and veins, relationship between vessels and nidus, and location of the nidus to brain surface. Display of the brain surface and superficial vessels is a guide in locating the nidus when the nidus is confined to a normal brain (2). Neurosurgeons must also know whether the arterial supply of the AVM does or does not feed the surrounding brain tissue. The DSA-MR fusion images can provide all the information for neurosurgeons.
Information on gyri and their relation to the lesions and vasculature can be obtained from a single image on the DSA-MR fusion image. Using this advanced image fusion technique coupled with its reasonable post-processing time, neurosurgeons may more easily and precisely understand the surgical anatomy preoperatively than analyzing 3D DSA and MR images separately.

In conclusion, this study showed that, in AVM cases associated with intracerebral hematoma, DSA-MR fusion images provided useful additional information for treatment planning to $3 D$ DSA, MR images, or both with no additional invasiveness. It may be worthwhile using DSA-MR fusion images as a part of the pretreatment assessment of cerebral AVMs considering their clarity and reasonable post-processing time.

\section{DECLARATION of INTEREST}

The authors declare that they have no conflict of interest.

\section{REFERENCES}

1. Bednarz G, Downes B, Werner-Wasik M, Rosenwasser RH: Combining stereotactic angiography and $3 \mathrm{D}$ time-of-flight magnetic resonance angiography in treatment planning for arteriovenous malformation radiosurgery. Int J Radiat Oncol Biol Phys 46:1149-1154, 2000

2. Kesava P, Baker E, Mehta M, Turski P: Staging of arteriovenous malformations using three-dimensional time-of-flight MR angiography and volume-rendered displays of surface anatomy. AJR 167:605-609, 1996

3. Ng I, Hwang PYK, Kumar D, Lee CK, Kockro RA, Sitoh YY: Surgical planning for microsurgical excision of cerebral arteriovenous malformations using virtual reality technology. Acta Neurochir 151:453-463, 2009

4. Ruggieri PM, Masaryk TJ, Ross JS, Modic MT: Intracranial magnetic resonance imaging. Invest Radiol 27 (Suppl 2): 33-39, 1992

5. Shimizu S, Suzuki H, Maki H, Maeda M, Miya F, Benali K, Trousset $Y$, Taki W: A novel image fusion visualizes the angioarchitecture of the perforating arteries in the brain. AJNR Am J Neuroradiol 24:2011-2014, 2003

6. Starke RM, Komotar RJ, Hwang BY, Fischer LE, Garrett MC, Otten ML, Connolly ES: Treatment guidelines for cerebral arteriovenous malformation microsurgery. $\mathrm{Br} \mathrm{J}$ Neurosurg 23:376-386, 2009

7. Suzuki H, Maki H, Maeda M, Shimizu S, Trousset $Y$, Taki W: Visualization of the intracisternal angioarchitecture at the posterior fossa by use of image fusion. Neurosurgery 56 : 335-342, 2005

8. Suzuki $H$, Shimizu S, Maki H, Maeda M, Sakaida H, Trousset Y, Taki W: Role of image fusion combining three-dimensional digital subtraction angiography with magnetic resonance imaging in evaluation of unruptured cerebral aneurysms. Neurol Res 29:58-63, 2007

9. Tsuchiya K, Katase S, Hachiya J, Shiokawa Y: Volume-rendered $3 \mathrm{D}$ display of MR angiograms in the diagnosis of cerebral arteriovenous malformations. Acta Radiol 44:675-679, 2003 